\title{
PENGETAHUAN, KEKUASAAN, DAN MOBILITAS SOSIAL DALAM NOVEL "DIVERGENT"
}

\author{
Miftah Nurul Irfan \\ Departemen Sosiologi Universitas Indonesia \\ e-mail: Miftahnurulirfan@gmail.com
}

\begin{abstract}
Abstrak
Tulisan ini membahas mengenai faktor yang mendorong terjadinya mobilitas sosial di masyarakat modern. Penelitian sebelumnya menemukan bahwa terjadinya mobilitas sosial di masyarakat modern disebabkan oleh faktor status ekonomi. Berbeda dengan penelitian sebelumnya yang cenderung melihat faktor ekonomi sebagai saluran mobilitas, penelitian ini melihat bahwa penguasaan terhadap pengetahuan dapat mendorong terjadinya mobilitas sosial pada masyarakat modern. Tak hanya itu, penguasaan seseorang atau kelompok terhadap pengetahuan akan menciptakan kelas elite baru di masyarakat. Metode yang digunakan dalam penelitian ini adalah kualitatif deskriptif dengan teknik analisis isi (content analysis) dan objek penelitian yang menceritakan kehidupan masyarakat modern dalam novel Divergent.

Abstract

This paper discusses the factors that encourage social mobility in modern society. The previous research found that social mobility in modern society are caused by factors of economic status. In contrast to previous research that only look at economic status as social mobility factors, this study want to see that the mastery of knowledge can lead to social mobility in modern society. Not only that, the mastery of knowledge will create a new elite class in the society. The method used in this study is descriptive qualitative approach with content analysis techniques. Content analysis is used to see and describe correlation between power, knowledge, and social mobility in modern society in Divergent novel.
\end{abstract}

Keywords : Modern society, knowledge, power, social mobility

\section{PENDAHULUAN}

Salah satu ciri masyarakat modern adalah adanya sistem stratifikasi yang lebih kompleks. Sistem stratifikasi yang kompleks menyebabkan seseorang mampu melakukan mobilitas sosial (Kerr, C. 1983). Penelitian mengenai mobillitas sosial sebelumnya dilakukan oleh
CASMIN (Comparative Analysis of Social Mobility in Industrian Nation) di sebelas negara industri di Eropa pada periode 1970 -an hingga 1990 -an yang memperlihatkan adanya peningkatan mobilitas sosial antar generasi di masyarakat modern (Breen, dalam Pattinasarany 2012). Selain itu, hasil survei International Social Survey 
Program (ISSP) di dua puluh negara pada tahun 1990 - an memperilhatkan adanya peningkatan mobilitas sosial antar generasi yang disebabkan oleh beberapa faktor, yaitu perkembangan ekonomi, pemerataan pendapatan, migrasi, sistem ekonomi negara, keterbukaan politik demokrasi, dan ideologi negara (Yais \& Andersen, 2012).

Studi yang dilakukan oleh Miles (1996) memperlihatkan bahwa masyarakat modern memiliki sistem stratifikasi terbuka sehingga individu memiliki kesempatan untuk melakukan mobilitas sosial. Miles menyebutkan bahwa pekerjaan dan prestasi kerja merupakan faktor dominan terjadinya mobilitas sosial. Industrialisasi membawa dampak terhadap pola mobilitas pada masyarakat modern dengan mengubah struktur pekerjaan. Bertambahnya jenis pekerjaan dan kebutuhan tenaga kerja mengakibatkan setiap orang memiliki kesempatan untuk memperbaiki kondisi ekonomi. Tak hanya itu, perkembangan jenis pekerjaan disebabkan oleh kemajuan di bidang ekonomi yang menempatkan seseorang pada jenis pekerjaan berdasarkan skill (Miles, 1996). Oleh karena itu, seseorang dapat memperoleh status dan kedudukan di masyarakat berdasarkan achieved status.

Selain pekerjaan, hasil penelitian lain memperlihatkan bahwa pendidikan memiliki kedudukan yang sangat penting dalam persaingan kerja (Ishida \& Miwa, 2005). Seseorang yang ingin menduduki posisi tertentu dalam suatu pekerjaan memerlukan tingkatan pendidikan yang kompeten. Pendidikan dituntut untuk memenuhi kebutuhan pasar kerja. Pendidikan dianggap dapat membuka peluang bagi seseorang untuk dapat memperoleh kesempatan kerja dan posisi sosial yang baik.

Sistem stratifikasi dan mobilitas sosial dalam novel Divergent mencerminkan realitas yang terjadi di masyarakat modern. Pembagian kerja masyarakat modern menunjukkan adanya kompleksitas berdasarkan fungsi dan keahlian. Selain itu, masyarakat modern ditandai dengan adanya pengetahuan dan rasionalitas yang berkembang pesat (Breen, 2004). Fungsi dan keahlian ini yang akan diturunkan oleh seseorang kepada generasi penerus mereka untuk tetap menjaga stabilitas sistem stratifikasi di masyarakat.

Senada dengan pernyataan Isihida dan Miwa, penelitian ini ingin menegaskan bahwa pendidikan yang dimaksud sebagai saluran mobilitas sosial tidak sebatas penjajakan pada jenjang pendidikan. Tetapi, pendidikan yang dimaksud adalah penguasaan seseorang atau kelompok terhadap pengetahuan yang diperoleh melalui pendidikan. Pengetahuan yang digambarkan dalam tulisan ini 
menekankan pada penggunaan discourse dan teknologi sebagai alat untuk mempertahankan kekuasaan seperti yang tercermin dalam novel Divergent. Oleh karena itu, penelitian ini melihat bahwa penguasaan pengetahuan mampu menciptakan power untuk mendorong terjadinya mobilitas sosial.

\section{KONSEP KEKUASAAN DAN PENGETAHUAN}

Francis Bacon (1597) menyebutkan "knowledge is power" yang mengartikan bahwa suatu ilmu pengetahuan merupakan sumber kekuasaan. Pendapat ini didasari oleh suatu keyakinan yang menyebutkan bahwa segala sesuatu yang menjadi persoalan manusia akan dapat terselesaikan dengan adanya pengetahuan. Sehingga, seseorang dapat menjadikan pengetahuan sebagai alat kekuasaan.

Pemikiran Bacon mengenai pengetahuan membawa dampak dan kemajuan yang sangat besar dalam perkembangan pengetahuan. Bacon melihat adanya peran yang sangat penting dari pengetahuan yang rasional, di mana tidak adanya dogma - dogma agama, tradisi, dan budaya yang dapat menghambat pemikiran manusia. Menurutnya, akan lebih baik seseorang mencari kebenaran sejati (pengetahuan) dari alam ketimbang berprasangka.

Bacon dalam bukunya Novum Organum (Garcia, 2001) mengatakan bahwa perlu adanya suatu terobosan pemikiran baru yang harus menggantikan pemikiran lama. Salah satunya adalah dengan cara membuang semua pandangan irasional yang diciptakan dan konstruksikan oleh tradisi. Oleh karena itu, perlu adanya metode baru yang harus diciptakan untuk menemukan kebenaran. Sebab, jika seseorang selalu berada pada bayang - bayang dogmatis dan hal yang irasional maka kehidupan tidak akan pernah berkembang.

Garcia (2001) dalam tulisannya mengenai Knowledge is Power : Francis Bacon to Foucault, mengemukakan bahwa pengetahuan menurut Bacon adalah segala bentuk eksperimen melalui studi, manipulasi dari fenomena alam. Bacon menyebutkan bahwa tujuan dari pengetahuan adalah untuk membebaskan manusia dari derita dan menyelesaikan kebutuhan manusia. Dalam upaya memenuhi kebutuhan manusia pengetahuan seseorang bukan hanya sebatas knowing, tetapi seseorang juga memerlukan action untuk mengaplikasikan suatu hal yang sudah di dapat dari pengamatan atau eksperimen. 
Sedangkan power yang dimaksud oleh Francis Bacon adalah suatu kekuatan atau kemampuan yang dimiliki seseorang untuk berkuasa. Power dipahami dalam beberapa bentuk, yaitu teknologi, strategi, dan kemampuan dalam berbicara. Bacon melihat bahwa kekuasaan yang dibangun oleh seseorang tidak dimunculkan dalam bentuk penindasan fisik, tetapi lebih menekankan kepada kemampuan untuk mengendalikan orang lain. Kemampuan untuk berkuasa tidak digunakan semata mata untuk melakukan penindasan. Meskipun, pada akhirnya power digunakan oleh seseorang maupun kelompok untuk menguasai dan melakukan dominasi.

Foucault (dalam Mudhoffir, 2013) melihat pengetahuan dan kekuasaan sebagai sebuah relasi yang tidak dapat dipisahkan. Berbeda dengan Bacon yang menyebutkan knowledge dan power dalam bentuk nyata yang mampu menguasai atau menekan pihak lain, Foucault melihat knowledge dan power dalam bentuk yang abstrak, menyebar, dan mampu menggerakan tubuh manusia untuk patuh. Foucault melihat pengetahuan sebagai sebuah rezim kekuasaan yang berkembang, berubah dan akan berganti dengan rezim yang baru. Foucault melihat pengetahuan bukan dalam bentuk teknologi, sains, melainkan dalam bentuk discourse yang dapat mendefinisikan pernyataan yang benar dan yang salah.

Bacon (dalam Ramirez, 2014) menyebutkan bahwa terdapat empat hal yang dapat menghalangi pemahaman manusia dan mencegah manusia dalam mencari kebenaran. Bacon dalam Ramirez (2014) , terdapat empat hal yang dapat menghalangi pemahaman manusia dan mencegah manusia dalam mencari kebenaran. Keempat hal atau gagasan tersebut adalah, tribe, cave, market dan theatre. Bacon melihat bahwa tribe dan cave merupakan dua hal yang tidak dapat dipisahkan, mereka merupakan bawaan seseorang dan membentuk kerangka berpikir seseorang dalam memandang sesuatu. Sedangkan market dan theatre dua hal yang terdapat dalam diri seseorang seiring dengan berkembangnya pikiran mereka dalam melihat kebenaran.

Bacon mengatakan bahwa dalam tribe dan cave terdapat hal yang dapat menghalangi kemajuan pengetahuan, yaitu takhayul. Takhayul menurutnya merupakan sumber penyimpangan yang merusak kebenaran akan pengetahuan. Selain takhayul, teologi juga merupakan hal yang dapat merusak tatanan ilmu pengetahuan. Sebab, kedua hal tersebut berusaha untuk membatasi dan mempertahankan pemikiran - pemikiran yang dapat menguntungkan mereka. Hal 
yang paling jelas adalah pada masa itu, banyak pemikiran teologi dan takhayul yang dimasukan ke dalam praktek politik (Larrain 20; Atkinson 39, dalam Ramirez 2014).

Bacon melihat bahwa terdapat persinggungan antara hal - hal yang bersifat dogmatis dengan pengetahuan. Terdapat kecenderungan seseorang untuk menanamkan ideologi dalam dogma dogma mereka. Dan, seringkali ideologi tersebut mewakili kepentingan dan kebutuhan suatu pihak. Salah satu hal yang dikritik oleh Bacon adalah posisi gereja pada masa itu yang sangat dipengaruhi oleh kepentingan para pemimpin yang sedang berkuasa.

Selain membahas mengenai pengetahuan sebagai hal yang penting dalam membawa kemajuan kehidupan, Bacon juga melihat bahwa terdapat peran bahasa dan komunikasi dalam menciptakan kekuasaan. Peran bahasa dan komunikasi tersebut muncul dan dimiliki oleh orang orang tertentu, terutama mereka yang berada pada kelas intelektual yang dapat menggunakan komunikasi dan bahasa dalam menciptakan kekuasaan.

Garcia (2001) mengatakan bahwa Bacon melihat adanya peran komunikasi pada kelas intelektual. Mereka menggunakan bahasa sebagai media untuk menciptakan suatu komunitas yang memiliki tempat eksekutif di masyarakat. Hal yang sama juga disebutkan oleh Bourdieu (1997) bahwa bahasa dan kemampuan berkomunikasi yang baik dapat dijadikan alat propaganda dan penanaman ideologi baru.

Bourdieu (dalam Wempi 2012) menyebutkan bahwa kemampuan bahasa yang dimiliki seseorang dapat menandakan kelas dan posisi sosial orang tersebut. Salah satu konsep Bourdieu yang menggambarkan kekuatan bahasa adalah symbolic power. Boudieu beranggapan bahwa linguistik merupakan bagian dari simbol - simbol yang menjadi modal sosial seseorang untuk dapat menguasai sesuatu. Simbol ini memiliki makna dan status untuk diakui dan diwujudkan dalam bentuk - bentuk objektif.

Sejalan dengan yang diungkapkan oleh Bacon, Bourdieu melihat bahwa kekuatan dari simbol berupa kemampuan berbahasa dapat membentuk suatu kelas sosial baru. Kapasitas simbol ini diproduksi secara terus menerus yang kemudian dapat menciptakan suatu distingsi dalam tatanan sosial. Kapasitas kapital simbolik ini berguna sebagai sumber kekuatan pemiliknya ketika berhadapan dengan agen lain yang memiliki kedudukan yang lemah. Tetapi, kekuatan yang diciptakan dari kapital simbolik ini tidak lepas dari keadaan 
budaya dan pengakuan masyarakat terhadap kedudukan simbol itu sendiri.

Bourdieu melihat bahwa kapital simbol ini membentuk kelas baru yang memiliki nilai dan norma yang sama. Agen akan saling menunjukkan simbol - simbol mereka secara formal dan mengakibatkan adanya distingsi pada kelas sosial yang lain. Sebagai contoh, Bourdieu menulis dalam karya besarnya Distincion: A Social Critique of The Judgment of Taste yang melihat bahwa suatu karya seni dari produk budaya dapat menciptakan selera berbeda dari lapisan sosial.

Bourdieu (dalam Garcia, 2001) menyebutkan bahwa salah satu produk dari pola simbolik yang digunakan untuk mendominasi dan menciptakan struktur kelas adalah discourse. Bourdieu merujuk kepada pemikiran Bacon, melihat bahwa discourse dapat menciptakan dominasi dan munculnya ideologi baru yang memengaruhi individu atau suatu kelompok. Pernyataan Bourdieu mengenai discourse berbeda dengan pandangan Foucault yang memandang discourse sebagai salah satu alat bekerjanya suatu kekuasaan yang memengaruhi tubuh seseorang. Bourdieu lebih melihat kepada adanya peran aktor dalam memengaruhi individu atau kelompok melalui discourse. Bacon dan Bourdieu memiliki kesamaan dalam melihat fungsi bahasa dalam kekuasaan dan kelas sosial. Baik Bacon maupun Bourdieu melihat bahwa kekuasaan dan pengetahuan yang dimiliki seseorang dapat menciptakan suatu kelas yang ahli dalam ilmu pengetahuan dan komunikasi. Dalam kelas ini muncul golongan intelektual yang mendapatkan promosi ekskutif tinggi untuk berkuasa.

\section{KEKUASAAN DAN MOBILITAS SOSIAL}

Mobilitas sosial merupakan suatu pergerakan individu dari satu posisi kelas ke posisi kelas sosial baru di masyarakat (Saunders, 2010). Pergerakan ini dilihat baik secara individu maupun secara kelompok. Singkatnya, mobilitas sosial menggambarkan adanya suatu peluang untuk bergerak antara kelompok sosial untuk meraih keuntungan berupa pendapatan, keamanan kerja, dan peluang untuk lebih maju (Aldrige, 2001).

Lipset dan Zetterberg melihat mobilitas sosial terjadi disebabkan adanya supply dari status yang tidak terisi, dan adanya pergantian ranking (Bendix dan Lipset, 1966: 565, dalam Pattinasarany 2012). Dimensi mobilitas yang digunakan oleh Lipset dan Zetterberg terdiri dari empat dimensi, yaitu ranking okupasi, ranking konsumsi, kelas sosial, dan ranking kekuasaan. 
Dalam tulisan ini, dimensi yang lebih menonjol dalam analisis mobilitas sosial adalah ranking kekuasaan. Ranking kekuasaan merujuk kepada hubungan peran berupa hubungan otoritas yang melibatkan adanya posisi subordinate dan superordinate. Lipset yakin bahwa kekuasaan merupakan kendaraan mobilitas sosial (Bendix dan Lipset, 1966, hal :564, dalam Pattinasarany 2012).

\section{METODE PENELITIAN}

Penelitian ini menggunakan pendekatan kualitatif dengan metode deskriptif analitik. Penelitian dengan metode deskriptif analitik merupakan penelitian yang bermaksud untuk memahami fenomena yang dialami subjek secara holistik, dengan mendeskripsikan konteks khusus (Neuman, 2010). Metode deskriptif analitik dilakukan dengan cara mendeskripsikan fakta - fakta yang disusul dengan analisis (Ratna, 2009).

Teknik penelitian yang digunakan adalah analisis isi (content analysis). Penelitian menggunakan analisis isi yang lebih bersifat kualitatif dengan menekankan pada pemahaman teks. Dasar dari deskripsi analisis isi menekankan pada interpretasi dan penafsiran peneliti (Krippendorf, 1980). Teknik analisis isi ini digunakan untuk melihat dan mendeskripsikan pengetahuan sebagai sumber kekuasaan yang dapat mendorong terjadinya mobilitas sosial masyarakat modern seperti yang digambarkan dalam novel Divergent. Data yang digunakan dalam tulisan ini berupa data kualitatif yang terdapat dalam novel seperti, alur, tema, latar, amanat, tokoh, sudut pandang, dan gaya bahasa.

Selain itu, penelitian ini dilakukan berdasarkan empat tahap, yaitu pengumpulan data, penyeleksian data, analisis data, dan penarikan kesimpulan. Tahapan pengumpulan data, penulis membaca dan mengumpulkan data berupa kata dan kalimat yang menunjukkan adanya hubungan antara pengetahuan dan kekuasaan. Tahapan penyeleksian data dilakukan dengan memilah data - data relevan yang telah dikumpulkan untuk melihat adanya relevansi data terhadap analisis. Tahapan analisis data dilakukan setelah terkumpulnya data - data yang dianggap relevan dan sesuai dengan konsep penelitian. Analisis dilakukan untuk melihat data lebih dalam yang berhubungan dengan konsep. Tahapan penarikan kesimpulan dilakukan setelah semua data yang didapat dan dipilih selesai dianalisis. Penarikan kesimpulan dilakukan untuk melihat kaitan antara satu data dengan data lainnya. Sehingga, dapat membentuk suatu hubungan antara data dengan konsep. 


\section{SINOPSIS NOVEL DIVERGENT}

Novel ini menceritakan kondisi Chicago sebagai negara bagian pasca terjadinya perang besar yang melanda dunia. Masyarakat hidup dalam kota yang dikurung dalam pagar besar yang ditujukan untuk melindungi masyarakat serta menciptakan kedamaian dari pengaruh dunia luar. Selain dibangunnya pagar pelindung, masyarakat dalam cerita ini digambarkan dibagi ke dalam lima faksi berdasarkan fungsi dan kedudukan mereka di masyarakat. Pembagian masyarakat ke dalam lima faksi ini dianggap sebagai cara yang paling ideal untuk menjaga masyarakat tetap damai dengan adanya kelompok - kelompok yang menjalankan fungsi mereka masing - masing.

Kelima kelompok faksi tersebut memiliki dan saling menghormati aturan serta moral tunggal yang diciptakan dalam setiap faksi. Mereka hidup berdasarkan nilai - nilai kelompok yang mereka bangun. Mereka membatasi segala sesuatu yang berhubungan dengan faksi lain di luar faksi mereka. Penempatan seseorang dalam suatu faksi juga dikontrol dengan berupaya sebaik mungkin tidak terjadi adanya perpindahan faksi. Sehingga, segala bentuk interaksi yang terjadi antar faksi hanya sebatas kepentingan umum.
Abnegation, sebagai faksi yang menggambarkan kehidupan sederhana, menolak kesombongan, tidak korupsi, menjunjung tinggi nilai kejujuran, dan mendedikasikan hidup untuk bekerja pada masyarakat (social service). Mereka menggunakan pakaian berwarna abu - abu kusam dan melarang setiap anggotanya untuk menggunakan perhiasan. Erudite menggambarkan kelompok dengan ilmu pengetahuan yang sangat tinggi. Mereka menguasai dan menciptakan teknologi, perkembangan ilmu pengetahuan sains dan sosial, mengembangkan dan menciptakan sistem pertahanan, dan pemikiran pemikiran baru yang dianggap memajukan kehidupan masyarakat. Salah satu ciri khas dari faksi Erudite adalah pakaian yang berwarna biru yang dianggap menggambarkan kejernihan pikiran.

Condor adalah faksi yang menggambarkan kelompok masyarakat yang sangat menjunjung tinggi hukum. Condor bertugas untuk melegalkan kebijakan - kebijakan yang dibuat untuk diterapkan dalam kehidupan masyarakat. Nilai yang dianut oleh faksi ini adalah nilai kejujuran dan ketegasan. Hal tersebut tercermin dari warna yang menjadi ciri khas mereka, yaitu hitam dan putih. Dauntless merupakan faksi yang digambarkan memiliki ketangguhan, keberanian, dan pantang menyerah. Faksi 
ini adalah faksi yang bertugas sebagai pelindung atau tentara di kota Chicago. Karakter dari faksi ini terlihat jelas dari atribut yang digunakan, yaitu adanya tattoo di tubuh setiap anggota, pakaian hitam dan merah (dominan hitam), menggunakan tindik di alis atau kupingnya.

Sedangkan Amity adalah kelompok pekerja, buruh perkebunan yang bekerja untuk menyediakan kebutuhan pangan bagi kelompoknya dan seluruh faksi lain dalam kota Chicago. Mereka mengelola perkebunan dan bermukim di luar pagar kota. Nilai keceriaan dan kebersamaan menjadi identitas mereka yang tercermin dalam pakaian dan warna yang mereka kenakan. Terdapat satu kelompok yang juga terdapat dalam cerita ini, yaitu factionless. Kelompok tanpa faksi adalah mereka yang tidak memiliki dan tidak diakui oleh faksi manapun. Sebab, mereka adalah orang - orang yang melakukan pelanggaran terhadap nilai dan norma dari faksi mereka, selain itu mereka tidak mampu bertahan dalam ujian adaptasi untuk menentukan faksi seseorang.

Konteks mengenai latar, alur, dan kejadian dalam cerita ini membawa pembacanya mengandaikan kondisi dunia di masa depan. Kondisi dunia dimana masyarakat yang telah lelah dengan para pemimpin cerdas yang korup, tidak bermoral, dan mengabaikan nilai - nilai kebaikan. Keadaan seperti ini yang kemudian membawa manusia untuk berfikir bahwa akan lebih baik negara mengangkat pemimpin yang tidak memiliki kecerdasan intelektual yang tinggi, tetapi menjunjung tinggi kebaikan, kejujuran, dan kesederhanaan. Meskipun, pada akhirnya akan ada perlawanan dari mereka yang menguasai kecerdasan intelektual dan megakibatkan adanya penggulingan kekuasaan.

\section{STRATIFIKASI SOSIAL DALAM NOVEL DIVERGENT}

Masyarakat yang terbagi ke dalam enam kelompok faksi membawa nilai serta norma yang menjadi identitas mereka ketika berada dalam masyarakat. Setiap faksi menempati fungsi dan posisi yang berbeda - beda dalam tatanan kehidupan negara. Posisi mereka dalam kelas sosial ditentukan berdasarkan adanya legitimasi dan fungsi yang paling menonjol untuk memimpin dan mengatur seluruh kebijakan faksi. Dalam novel ini, diceritakan bahwa Abnegation merupakan faksi yang memiliki posisi tertinggi dalam masyarakat. Posisi tertinggi ini didapatkan atas dasar keputusan legal dan rasional yang diadakan ketika pembentukan faksi terjadi. Alasan Abnegation dipilih sebagai pemimpin dari semua faksi karena nilai nilai yang dianut oleh kelompok mereka, 
seperti kejujuran, tidak korupsi, menolak kemewahan, yang dianggap masyarakat sesuai dengan nilai yang harus dimiliki oleh setiap pemerintahan. Hal ini ditunjukkan oleh dialog berikut:

"Pemimpin kami dipilih oleh rekan rekannya karena karakter yang tidak tercela, kegigihan moral, dan watak kepemimpinan. Perwakilan dari faksi lainnya bisa berbicara di dalam sebuah pertemuan tentang masalah tertentu, tetapi keputusan sepenuhnya berada di tangan dewan”. (Roth, 2011, Chapter 4, hal: 44).

Kesederhanaan Abnegaton tercermin dari pakaian yang mereka kenakan, warna baju abu - abu yang menggambarkan kesederhanaan. Mereka juga tidak mengonsumsi makanan secara berlebihan, tidak mengenakan perhiasan mencolok (hanya jam tangan), menolak untuk terlalu lama bercermin karena dianggap akan memunculkan kesombongan, dan tinggal dirumah sederhana dengan jendela dari besi kusam serta tembok rumah yang tidak dicat. Kesederhanaan juga tergambar dalam nilai makan Abnegation seperti dalam dialog berikut:

“.. Itu daging sapi” Kata Four sambil menyikutku. “ Oleskan di atasnya, apa kau tak pernah melihat humberger sebelumnya?”. “Tidak .." Kataku

"Orang kaku (Abnegation) hanya makan - makanan sederhana" ujar
Four kepada Christina. "Kemewahan dianggap menye-nangkan diri sendiri dan tak perlu dilakukan" (Roth, 2011, Chapter 7: 82)

Erudite menempati posisi kelas sosial kedua di bawah Abnegation. Hal yang paling mencolok dari Erudite adalah pakaian dan atribut yang mereka kenakan melambangkan diri mereka sebagai kaum dengan intelektualitas yang tinggi. Pakaian serba biru yang mereka kenakan melambangkan adanya energi positif dalam tubuh mereka untuk menjernihkan pikiran. Warna biru merangsang tubuh mengeluarkan zat kimia yang bisa menyenangkan, pikiran yang tenang dan jernih (Roth, 2011, Chapter 24, hal:351).

Dalam hal penguasaan, Erudite memiliki penguasaan terhadap ilmu pengetahuan yang berkembang di masyarakat. Erudite menciptakan kebijakan dan mengembangkan perangkat teknologi yang lebih canggih, termasuk persenjataan. Mereka menguasai dan mengontrol penuh jalannya pendidikan di kota Chicago. Selain itu, Erudite juga memiliki hak untuk memilih pemimpin dari faksi Dauntless sebab mereka perlu melakukan pengawasan terhadap penggunaan persenjataan dalam kegiatan militer.

Dauntless dan Condor menduduki tempat atau posisi kelas sosial yang sama. 
Dauntless yang berperan sebagai tentara dan pelindung dari kota Chicago diberikan hak untuk menggunakan senjata dalam pengawasan Abnegation dan Erudite. Mereka hanya menerima perintah dan tidak diizinkan untuk menggunakan persenjataan diluar dari kepentingan keamanan kota. Pekerjaan Dauntless diantaranya, menjaga perbatasan atau bekerja untuk pengamanan kota, bekerja dalam markas Dauntless, menggambar tattoo sebagai bentuk identitas, membuat senjata, dan bekerja untuk para pemimpin Dauntless (Roth, 2011, Chapter 11, hal:147)

Amity menempati kelas sosial yang paling bawah dalam struktur masyarakat. Mereka tidak memiliki hak untuk memasuki kota selain saat waktu pengiriman makanan. Mereka hidup tidak dengan teknologi yang mewah seperti yang digunakan oleh Erudite, Dauntless, dan Condor. Mereka memiliki kehidupan yang sederhana dan selalu terlihat ceria meskipun mereka ditekan oleh kelompok yang lebih dominan. Sedangkan factionless tinggal tak jauh dari kelompok Abnegation. Mereka tinggal di gorong gorong, bekas tempat sampah, dan bekerja sebagai buruh serabutan yang mendapatkan imbalan berupa makanan dan pakaian (Roth, 2011, Chapter 4, hal 35).

Perbedaan bentuk stratifikasi sosial terjadi pada masa kekuasaan Erudite.
Kondisi ini berubah dimana masyarakat yang telah lelah dengan para pemimpin yang tidak korup, bermoral, dan hanya mementingkan nilai - nilai kebaikan. Keadaan seperti ini yang kemudian membawa masyarakat untuk berpikir bahwa akan lebih baik negara mengangkat pemimpin yang memiliki kecerdasan intelektual yang tinggi. Hal ini karena kondisi pasca perang yang dialami membuat berbagai macam permasalahan sosial, seperti sumber daya alam yang terbatas sehingga perlu dicari jalan keluarnya dengan mengembangkan pengetahuan.

Erudite dengan segala kemampuannya untuk menguasai sumber daya telah menggulingkan pemerintahan Abnegation yang tidak mengutamakan perkembangan pengetahuan dan menggantinya dengan kepentingan faksi Erudite. Erudite menunjukkan bahwa pengetahuan adalah segalanya dalam kehidupan. Erudite melihat prinsip bahwa perlu adanya suatu perlawanan untuk merubah pemikiran pemikiran lama dari pemerintah yang tidak rasional dengan pemikiran baru rasional. Sebab, suatu bangsa tidak akan pernah mengalami kemajuan apabila masih percaya akan dogma - dogma lama dan segala sesuatu yang tidak rasional.

Selain adanya upaya penanaman ideologi baru berdasarkan pengetahuan, 
dalam pemerintahannya Erudite menempatkan faksi - faksi terkuat dan memiliki kecerdasan tinggi sebagai kelompok yang memiliki posisi teratas. Salah satu faksi yang mendapatkan tempat penting dalam pemerintahan Erudite adalah Dauntless, sebab Erudite menggunakan kekuatan fisik Dauntless untuk mengukuhkan dan mempertahankan status mereka di pemerintahan.

Perubahan stratifikasi sosial saat Abnegation berkuasa di pemerintahan dan setelah adanya perubahan kekuasaan yang diambil alih oleh Erudite dapat dilihat dari gambar berikut:

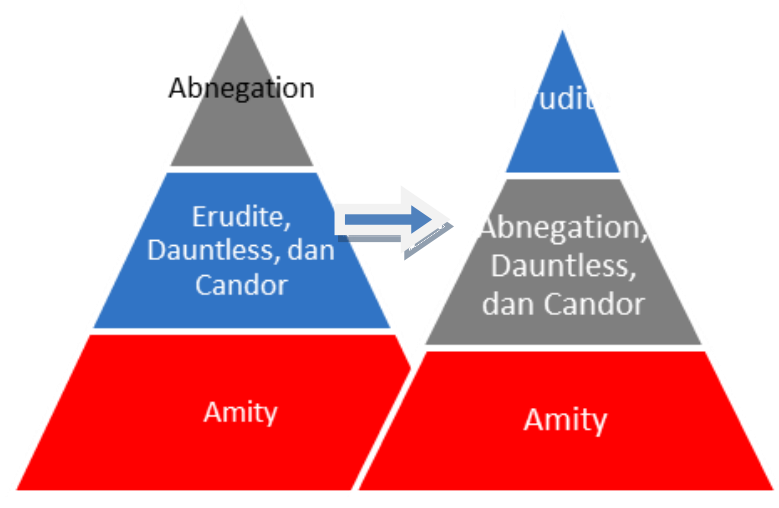

Gambar 1 : Perubahan Stratifikasi Sosial

\section{PENGUASAAN PENGETAHUAN}

Pengetahuan dalam cerita ini diperlihatkan melalui keberadaan sekolah sekolah yang dibangun untuk anak - anak dari setiap faksi. Semua anak dari setiap faksi mengenyam pendidikan, tetapi jenjang pendidikan formal mereka hanya sampai pada usia 16 tahun. Pendidikan selanjutnya mereka terima melalui proses pembelajaran kehidupan dalam faksi masing - masing. Sehingga, pengetahuan yang berkembang hanya berdasarkan pemahaman terhadap nilai - nilai dan cara hidup dari masing - masing, khususnya Abnegation. Abnegation yang menolak adanya pengetahuan sains dan sosial dalam kelompok mereka. Sebab, menurut Abnegation pengetahuan dan pendidikan akan membawa seseorang pada kesombongan dan mementingkan diri sendiri. Sehingga pengetahuan hanya berkembang pada faksi Erudite yang memiliki pandangan hidup mengutamakan pendidikan.

Selain pengetahuan dalam pendidikan, bentuk dari pengetahuan adalah adanya penggunaan media sebagai alat media komunikasi. Media dalam cerita ini menunjukkan bagaimana pengetahuan diproduksi oleh kelas tertentu di masyarakat. Seperti yang dikatakan oleh Bourdieu bahwa terdapat kelas - kelas sosial tertentu yang memproduksi pengetahuan dan menebarkannya dalam bentuk ideologi. Dalam hal ini, Erudite sebagai kelas yang menonjolkan ilmu pengetahuan dan intelektualitas memiliki kecakapan dalam melakukan komunikasi dan menggunakan bahasa. Erudite mengendalikan dan memuat berbagai 
macam informasi dari hasil eksperimen dan pemikiran - pemikiran mereka.

Dengan adanya penguasaan terhadap komunikasi dan bahasa serta ilmu pengetahuan mengakibatkan Erudite menyebarkan propaganda melalui berbagai media untuk menggulingkan pemerintahan Abnegation. Seperti yang dikatakan oleh Bourdieu bahwa seseorang atau kelompok yang memiliki penguasaan terhadap pengetahuan dapat memiliki kekuasaan untuk mendominasi orang lain. Tak hanya itu, gambaran mengenai propaganda melalui wacana yang dilakukan Erudite terhadap masyarakat adalah bentuk dari symbolic capital, di mana wacana sebagai simbol - simbol yang digunakan untuk dapat melakukan dominasi terhadap kelas yang lebih lemah.

Ambisi Erudite untuk berkuasa didukung oleh kondisi masyarakat yang digambarkan dalam novel. Seperti yang dijelaskan sebelumnya, kondisi masyarakat dalam novel Divergent adalah masyarakat yang baru bangkit dari keterpurukan akibat perang besar yang melanda wilayah mereka. Kondisi pasca perang mengakibatkan terjadinya berbagai kelangkaan dan akses. Masyarakat menginginkan hidup mereka dapat terlepas dari berbagai permasalahan tersebut. Oleh karena itu, masyarakat merasa bahwa perlu adanya inovasi terhadap teknologi untuk membangkitkan dan membangun kembali kehidupan yang lebih baik. Hal ini sejalan dengan pendapat Bacon mengenai pengetahuan yang berguna untuk menyelesaikan masalah dalam kehidupan (Garcia, 2001).

Selain adanya propaganda terhadap pemerintahan, Erudite juga menciptakan teknologi khususnya persenjataan. Erudite sebagai kelompok yang sangat mengerti mengenai teknologi dan memiliki hak dalam mengembangkan persenjataan memanfaatkan Dauntless untuk membantu melakukan perlawanan terhadap pemerintahan. Keinginan ini diikuti oleh Dauntless karena selama ini pemimpin mereka dipilih oleh pemimpin Erudite.

Sesuai dengan analisis mengenai penguasaan terhaadap pengetahuan yang dapat memunculkan adanya kelas baru di masyarakat, posisi Erudite sebagai kelompok intelektual dan memiliki penguasaan terhadap pengetahuan muncul sebagai kelas penguasa baru. Hal ini disebabkan karena kemampuan mereka untuk mengatur, menciptakan, dan mengendalikan orang - orang yang tidak memiliki pengetahuan sebaik mereka. Selain itu, adanya pengakuan dari masyarakat dan kelas lain terhadap kelas intelektual Erudite sebagai orang yang memiliki pengetahuan tinggi dan dominasi terhadap kelas lain. Pernyataan ini sejalan 
dengan fungsi pengetahuan yang diutarakan oleh Bourdieu bahwa pengetahuan mampu membentuk kelas baru di masyarakat dan menjadi dominan.

Erudite menggunakan berbagai studi dan pemikiran mereka untuk menyelesaikan permasalahan yang dihadapi oleh pemerintahan kota di bawah Abnegation. Pengetahuan adalah satu satunya solusi logis untuk menyelesaikan permasalahan terkait kemiskinan dan keamanan. Erudite mengembangkan berbagai ilmu pengetahuan untuk menunjukkan bahwa perlu adanya pemikiran yang rasional terhadap kehidupan masyarakat. Seperti yang dikatan Bacon mengenai rasionalitas, yaitu suatu kelompok atau masyarakat berpikir berdasarkan dogma - dogma lama tidak akan memikirkan kebenaran dari pengetahuan dan kemajuan dalam kehidupan tidak akan terjadi.

Tujuan utama dari Erudite adalah ingin untuk menghapuskan pemikiran lama yang melihat bahwa pengetahuan bukan suatu hal yang penting di masyarakat. Seperti yang telah dibahas sebelumnya bahwa Abnegation sebagai pemimpin faksi melihat bahwa pengetahuan bukanlah hal yang paling dibutuhkan oleh masyarakat dalam membentuk kedamaian ideal, melainkan kejujuran dan kebaikan moral adalah yang paling dibutuhkan di masyarakat. Erudite muncul sebagai pihak baru yang berupaya menghapus dogma dogma dan tradisi yang dianggap tidak masuk akal dan tidak mampu menyelesaikan masalah.

Sejalan dengan pemikiran Bacon, Erudite melihat bahwa pengetahuan merupakan suatu hal yang krusial. Tanpa adanya pengetahuan dan upaya untuk mendapatkan kebenaran, seseorang hanya akan hidup dalam kebohongan dan dogma dari pihak yang berkepentingan (penguasa). Sehingga perlu adanya pembaharuan cara berpikir ke arah yang lebih rasional, yaitu dengan mengembangkan pengetahuan.

Selain itu, penggunaan atribut, kemampuan berbahasa, dan bentuk nilai dan norma dalam setiap faksi menunjukkan bahwa adanya distingsi dalam setiap kelompok yang menunjukkan kelas. Seperti yang diungkapkan Bourdieu dalam bukunya mengenai distingsi kultur, setiap faksi dalam novel ini menunjukkan distingsi - distingsi tersebut berdasarkan atribut, penggunaan bahasa, pemberlakukan nilai dan norma yang mampu menunjukkan selera dari budaya yang berlaku dalam setiap kelompok, serta dapat menunjukkan posisi kelompok dalam hierarki kelas. 
BENTUK

PENGEMBANGAN

PENGETAHUAN

YANG

DILAKUKAN ERUDITE

Erudite mengembangkan beberapa studi dalam upaya menyelesaikan masalah dan membuat kebijakan di masyarakat. Beberapa bidang studi yang dikembangkan Erudite terkait dengan ilmu pengetahuan yang dapat diaplikasikan di masyarakat, seperti Sosiologi, Matematika, Komunikasi, dan Sejarah. Studi - studi tersebut diaplikasikan secara langsung oleh Erudite untuk membantu tatanan masyarakat yang ideal.

Dalam mengembangkan ilmu Sosiologi, Erudite membagi masyarakat ke dalam beberapa kelompok faksi yang sesuai dengan peran dan fungsi mereka di masyarakat. Hal ini sejalan dengan pemikiran struktural fungsional yang melihat masyarakat ideal berdasarkan peran dan fungsi yang dijalankan di masyarakat. Selain itu, pembagian masyarakat ke dalam peran dan fungsinya bertujuan untuk mencegah adanya konflik di masyarakat.

Dalam ilmu Matematika Erudite mengembangkan ilmu pengetahuan eksakta dan teknologi. Beberapa bentuk pengembangan dalam sains adalah menciptakan bahan kimia yang dapat membuat orang patuh terhadap perintah, formulasi yang dapat mengendalikan dan melihat alam bawah sadar seseorang, serta seperangkat bahan ujian yang digunakan untuk menentukan seseorang dalam suatu faksi. Dan, dalam bidang teknologi, Erudite berperan besar dalam menciptakan teknologi - teknologi yang terdapat di kota Chicago. Kontribusi teknologi yang paling besar terdapat pada persenjataan yang digunakan oleh Dauntless untuk melindungi kota.

Dalam mengembangkan komunikasi, Erudite mengajarkan dan menggunakan gaya dan cara berbahasa yang sangat baik, khususnya dalam faksi mereka. Erudite menghasilkan bermacam - macam informasi yang dibutuhkan oleh masyarakat. Selain itu, Erudite juga melakukan berbagai hal yang berkaitan dengan penyebaran informasi melalui media.

Dalam ilmu Sejarah, Erudite melihat berbagai hal yang menjadi kesalahan sebelum terjadinya perang. Dengan memahami berbagai kesalahan, mereka berupaya untuk mengganti dan merubah kebijakan yang dirasa kurang berhasil dengan berbagai kebijakan yang baru. Erudite berpandangan bahwa perlu adanya perubahan dari tatanan yang dulu sebelum perang besar terjadi ke dalam tatanan baru yang lebih baik.

Berbagai pengetahuan dan pembaruan yang dilakukan Erudite membawa 
kemajuan dan dapat menyelesaikan masalah dalam bidang politik, ekonomi, dan sosial. Dalam bidang politik, pengetahuan membentuk perubahan terhadap efisensi pemerintahan. Efisiensi pemerintahan dilakukan dengan melakukan perubahan sistem birokrasi yang lebih efektif. Selain itu, pengembangan teknologi juga dilakukan dalam praktek politik.

Pada bidang ekonomi, Erudite mengembangkan teknologi untuk pertanian dan perkebunan faksi Amity. Teknologi tersebut dapat membantu faksi Amity untuk mendapatkan hasil pertanian dan perkebunan yang melimpah dan berkualitas baik. Pengembangan teknologi dilakukan dengan cara mengembangkan bibit tanaman yang berkualitas baik. Selain itu, air dalam sistem irigrasi yang tercemar akibat adanya perang dibuat menjadi air yang baik bagi tanaman dan ternak. Erudite membuat perhitungan agar tanah yang dijadikan pertanian dan perkebunan dapat tercukupi dan memenuhi kehidupan seluruh masyarakat.

\section{PERAN AKTOR}

Keberhasilan Erudite dalam melakukan mobilitas sosial sebagai pemimpin faksi tidak terlepas dari peran Jeanine Matthews. Jeanine adalah seorang pemimpin dari faksi Erudite yang terpilih berdasarkan rangking IQ - nya (Roth, 2011, Chapter 4, hal:45). Jeanine memiliki peran yang penting dalam upaya mobilitas Erudite untuk menggeser pemerintahan Abnegation.

Salah satu upaya yang dilakukan Jeanine dalam merebut posisi Abnegation sebagai penguasa adalah dengan menyebarkan ancaman dan propaganda melalui media. Erudite sebagai kelas intelektual yang menguasai komunikasi dan bahasa memanfaat kemampuan mereka untuk melakukan propaganda terhadap pemerintah. Propaganda dilakukan dengan menanamkan isu politik kepada publik tentang keburukan dan kesalahan Abnegation selama menjalani pemerintahan. Isu tersebut ditujukan khususnya kepada pemimpin Abnegation, Marcus yang juga merupakan pemimpin dari pemerintahan.

Erudite dalam upaya penguasaannya menerbitkan tiga artikel bernada propaganda terhadap Abnegation. Artikel pertama adalah mengenai tuduhan bahwa Abnegation melakukan penimbunan bahan - bahan makanan seperti buah dan sayuran segar untuk kebutuhan fraksi mereka sendiri. Artikel kedua membahas mengenai gagalnya sistem pemilihan pegawai pemerintah berdasarkan asal faksi. Erudite mempertanyakan dalam artikelnya "Mengapa hanya mereka yang 
menganggap dirinya tak memiliki pamrih?". Erudite mengajukan kembali sistem pemilihan yang demokratis seperti sistem di masa lalu, di mana kepemimpinan dipilih secara demokratis. Artikel ketiga menyinggung mengenai kegagalan pemerintah dalam hal mengentaskan kemiskinan (Roth, 2011, Chapter 21, hal:296).

Bahasan mengenai apa yang dilakukan Erudite memperlihatkan adanya pihak yang memiliki kemampuan untuk menguasai sumber daya dan dapat menggunakan keseluruhan aspek sumber daya sebagai alat kekuasaan. Erudite menjadikan media massa sebagai alat hegemoni untuk menggulingkan pemerintahan sebelumnya dan juga untuk menanamkan ideologi baru di masyarakat serta kontrol terhadap kota. Dalam hal ini, masyarakat dijadikan objek pasif untuk melanggengkan kekuasaan mereka.

Media massa ini cukup aktif dalam penyerangan politik. Hal ini juga karena Erudite mempunyai data bahwa masyarakat yang ada sangat pasif dalam menanggapi arus informasi yang tersebar. Faksi lain lain tidak kritis menanggapi informasi yang ada. Informasi yang ada diserap begitu saja oleh faksi lain. Alhasil media massa ini menimbulkan sentimen faksi lain kepada Abnegation yang sedang memegang pemerintahan. Hal ini dapat dilihat dari dialog berikut:

"Kau tahu siapa dia?" Cara menunjuk ibu. "Ia itu istri anggota dewan yang, ya begitulah.”. "Ia menjalankan agensi sukarelawan yang seharusnya menolong para factionless. Kau pikir aku tidak tahu kalau kau sebenarnya menumpuk barang - barang yang nantinya akan kau bagikan ke faksimu sendiri, sementara kami tidak mendapatkan makanan segar selama sebulan?" (Roth, 2011, Chapter 15:212)

Dialog di atas memperlihatkan bagaimana bekerjanya modal simbolik pengetahuan melalui bahasa yang memproduksi citra dan membangun kekuatan realitas. Bekerjanya modal bahasa tidak lepas dari dari peran aktor dan struktur yang berkepentingan untuk mengonstruksi simbol. Aktor atau kelompok yang berkuasa memiliki kekuatan simbolik untuk mengonstruksi realitas sesuai dengan ideologinya. Wacana dibuat bergantung dari siapa yang memproduksi wacana tersebut (Bourdieu, 1977). Dalam hal ini, wacana yang dibangun berfungsi untuk menanamkan ideologi Erudite dan menggiring faksi lain ke dalam kerangka berpikir Erudite.

Cara penanaman ideologi melalui perubahan nilai dan norma yang ada di 
setiap kelompok. Menurut Marx ideologi merupakan ide-ide yang dikonstruksikan oleh kelas penguasa. Dari pengertian inilah ideologi digambarkan sebagai kepentingan kelas berkuasa untuk mempertahankan status quo, beragam cara yang dilakukan kelas penguasa untuk memanipulasi nilai dan norma yang menjadi alat oppression kelompok lain. Erudite berusaha menciptakan keseimbangan dan tatanan yang ada agar tidak menimbulkan perang yang memperebutkan sumber daya yang terbatas.

Selain melakukan propaganda, Jeanine juga mengendalikan pelatihan dan mengatur perilaku standar Dauntless. Jeanine juga melakukan penggantian pemimpin Dauntless dan merubah metode bekerja Dauntless sebagai tentara untuk menjadi lebih kompetitif. Perubahan ini membawa dampak yang besar terhadap keseluruhan perilaku Dauntless (Roth, 2011, Chapter 18, hal:272 - 273). Tak hanya itu, Dauntless yang semula dibentuk untuk menjadi pelindung bagi semua faksi dan membawa nilai - nilai kebaikan sebagai penolong dan pelindung telah berubah menjadi Dauntless yang bersikap kasar dan melakukan penindasan fisik terhadap faksi lain (Roth, 2011, Chapter 16, hal:235).

Bukti yang menunjukkan peran Jeanine dalam mengendalikan Dauntless terlihat dari pernyataan Jeanine yang menjanjikan tempat bagi para faksi lain di pemerintahan ketika Erudite berkuasa.

"Aku bukan orang bodoh" kata Jeanine. "Kami telah didominasi oleh orang bodoh tanpa rasa pamrih yang menolak kekayaan dan kemajuan, tapi kami tidak bisa melakukannya sendiri. Dan, pemimpin Dauntless dengan senang hati menurutiku jika aku menjamin mereka duduk di pemerintahan baru kami yang berkembang” (Roth, 2011, Chapter 33, hal:475).

Analisis mengenai peran aktor merujuk kepada pemahaman Bacon mengenai knowledge and power, yaitu Bacon melihat bahwa adanya atau munculnya kekuasaan dikarenakan seseorang yang memiliki pengetahuan bergerak untuk membentuk kekuasaan. Aktor yang dimaksud adalah subjek yang menjalankan perannya untuk membentuk kekuasaan dari pengetahuan yang dimilikinya. Berbeda dengan Foucault yang melihat bahwa relasi power and knowledge sebagai sesuatu yang tak terlihat dan menyebar, Bacon dan Bourdieu lebih merujuk kepada adanya seseorang (figure) yang mampu menjalankan kekuasaan. 
PENGETAHUAN DAN MOBILITAS SOSIAL

Dalam tulisan ini, mobilitas terjadi karena adanya kaum intelektualitas yang mampu menguasai sumber daya langka di masyarakat. Sumber daya yang terdapat dalam cerita ini bukan dalam bentuk ekonomi semata, melainkan keseluruhan pengetahuan yang dapat memperbaiki hidup masyarakat. Erudite menunjukkan eksistensinya dalam penguasaan terhadap pengetahuan.

Seperti yang diungkapkan oleh Bacon bahwa pengetahuan merupakan sumber dari terciptanya kekuasaan. Seseorang atau kelompok yang awalnya tidak memiliki kekuasaan dan tidak menempati posisi kelas tertinggi dapat melakukan mobilitas dan menciptakan kekuasan tersebut melalui pengetahuan yang dimilikinya. Seperti yang diungkapkan oleh Lipset dan Zetterberg tentang dimensi mobilitas sosial, yaitu ranking okupasi, konsumsi, kelas sosial, dan ranking kekuasaan.

Yang dimaksud sebagai dimensi mobilitas sosial adalah kedudukan seseorang berdasarkan statusnya di masyarakat. Status tersebut dapat dilihat melalui pekerjaan seseorang di masyarakat, tingkatan dan jenis konsumsi seseorang yang menunjukkan gaya hidup, kelas sosial seseorang di masyarakat, dan tingkatan kekuasaan seseorang yang menunjukkan seberapa besar seseorang memiliki kekuasaan (Bendix dan Lipset, 1966, dalam Pattinasarany 2012).

Konteks mobilitas yang terdapat dalam cerita ini terletak pada ranking kekuasaan kelompok atau seseorang. Abnegation merupakan faksi yang menempati posisi kelas tertinggi, tetapi tidak memiliki ranking kekuasaan tertinggi di masyarakat. Sedangkan, Erudite adalah faksi yang tidak menempati ranking kelas sosial tertinggi, tetapi memiliki ranking penguasaan tertinggi di masyarakat. Hal inilah yang disebut Lipset dan Zetterberg sebagai adanya supply dari status yang tidak terisi.

Erudite memiliki ranking tertinggi dalam kekuasaan, sedangkan Abnegation memiliki ranking tertinggi dalam kelas sosial sehingga kedua faksi ini berbenturan akibat adanya peluang untuk mengisi kekosongan yang tidak dimiliki Erudite. Adanya pergantian ranking yang dialami oleh Erudite dan Abnegation. Erudite berupaya dan berhasil menempati posisi ranking Abnegation dalam ranking kelas, dan Abnegation mengalami penurunan ranking kelas dan ranking kekuasaan.

Adanya pergantian ranking tersebut memperlihatkan adanya mobilitas sosial dalam novel Divergent. Adanya pembuktian konsep yang dikemukakan Lipset dan Zetterberg mengenai mobilitas 
yang disebabkan adanya pergantian ranking kekuasaan. Selain itu, juga adanya pembuktian mengenai konsep yang dikemukakan Bacon bahwa pengetahuan dapat menciptakan kekuasaan dan membangun kelas penguasa baru.

\section{SIMPULAN}

Kekuasaan dapat tercipta dari adanya penguasaan terhadap pengetahuan. Dalam tulisan ini dapat digambarkan bahwa kekuasaan dan pengetahuan merupakan dua hal yang saling memengaruhi. Penguasaan terhadap pengetahuan yang dimaksud bukanlah mengenai seberapa tinggi seseorang mengenyam jenjang pendidikan, melainkan mengenai seberapa besar kemampuan yang dimiliki seseorang untuk dapat menguasai dan memahami apa yang telah dipelajari.

Bacon menuturkan dalam konsepnya bahwa pengetahuan seseorang dapat menciptakan kekuatan untuk menguasai sesuatu. Konteks terciptanya kekuasaan dari pengetahuan yang dikemukakan oleh Bacon tidak merujuk pada penciptaan kekuasaan melalui kekuatan dan penindasan fisik. Tetapi lebih kepada hal hal yang sifatya pengendalian terhadap perkembangan teknologi dan kontrol terhadap sumber daya. Kekuasaan yang disebutkan oleh Bacon juga tidak merujuk kepada pembentukan dominasi kelas superordinate terhadap kelas subordinate. Meskipun, pada akhirnya tidak dapat dipungkiri bahwa kelas penguasa dapat melakukan dominasi dan tekanan terhadap kelas subordinate.

Lipset dan Zetterberg dalam teorinya mengenai mobilitas sosial juga memperlihatkan bahwa kekuasaan memiliki peran dalam membentuk suatu kelas dominan. Adanya peluang dan supply untuk mengisi kekosongan kelas mengakibatkan adanya dorongan untuk terjadinya mobilitas pada suatu kelompok. Dorongan dan peluang ini sesungguhnya diciptakan sendiri oleh masyarkat melalui saluran - saluran mobilitas yang salah satunya tergambar jelas dalam novel ini, yaitu pengetahuan.

Melalui penggambaran cerita, dialog, dan analisis yang dibangun dalam novel ini memperlihatkan bagaimana pengetahuan merupakan hal yang sangat penting di masyarakat. Pengetahuan membuka pemikiran seseorang untuk menciptakan segala sesuatu yang dianggap dapat memudahkan dan menyelesaikan masalah dalam kehidupan sehari - hari. Dan yang lebih penting, keahlian yang diciptakan melalui pengetahuan dapat memunculkan ide untuk berkuasa. Contoh nyata dari pemikiran Bacon dapat dilihat dari bagaimana Erudite dapat menciptakan kekuasaan dari pengetahuan dan keahlian 
yang mereka kuasai. Inilah yang disebut Bacon sebagai knowledge is power.

\section{DAFTAR PUSTAKA}

Aldrige, Stephen. 2001. Social Mobility: A Discussion Paper "Performance and Innovation Unit". London: Cabinet Office, Policy and Evaluation Unit. April 2001.

Bourdieu, Pierre. 1977. Outline of $a$ Theory of Practice. London: Cambridge University Press.

Breen, Richard (editor). 2004. Social Mobility in Europe. Oxford. Oxford: University Press

Garcia, Jose Maria R. 2001. Scientia Potestas Est- Knowledge is Power: Francis Bacon to Michel Foucault. Budapest: Neohelicon, Vol.28, No: 1.

Ishida, Hiroshi dan Satoshi Miwa. Social Mobility and Education in Postwar Japan. Tokyo: University of Tokyo Press

Kerr, C. 1983. The Future of Industrial Societies. Cambridge, Mass.: Harvard University Press.

Miles, Andrew. 1996. Social Mobility in nineteenth-century England. Refresh: Journal of Recent Findings of Research in Economic and Social History. Volume 23, Autum.

Mudhoffir, Abdil Mughis. 2013. Teori Kekuasaan Michael Foucault: Tantangan bagi Sosiologi Politik. Jurnal Sosiologi Masyarakat, Vol. 18, No. 1: $75-100$.

Pattinasarany, Indera Ratna I. 2012. Disertasi Mobilitas Sosial Vertikal Antar Generasi : Kajian Terhadap Masyarakat Kota di Provinsi Jawa Barat dan Jawa Timur. Depok:
Departemen Sosiologi, Universitas Indonesia.

Poloma, Margaret M. 2010. Sosiologi Kontemporer. Jakarta: PT Rajagrafindo Persada

Ramirez, dkk. 2014. Knowledge is Power. Francis Bacon's Theory of Ideology and Culture. La Mancha, Spain: Via Panorâmica: Revista Electrónica de Estudos Anglo-Americanos / An Anglo-American Studies Journal. Série 3, Número Especial (2014): 25-42.

Ritzer, George \& Douglass J. Goodman. 2003. Teori Sosiologi Modern. Alih bahasa Alimandan. Jakarta: Prenada Media.

Roth, Veronica. 2011. Divergent. Novel. Bandung: PT Mizan Pustaka.

Saunders, Peter. 2010. Social Mobility Myths. Institute for the Study of Civil Society. Wilthshire, London: Great Britain by Cronwell Press Group Trowbridge.

W. Lawrance Neuman. 2010. Social Research Methods: Qualitative and Quantitative Approaches: Boston: 139.

Wempi, Jefri Audi. 2012. Teori Produksi Kultural: Sebuah Kajian Pustaka. Exposure - Journal of Advanced Communication, Vol.2, No.1, Februari.

Yaish, Meir \& Robert Andersen. 2012. Social mobility in 20 modern societies: The role of economic and political context. Elsevier: Social Science Research 41: 527-538.

\section{Other Resource :}

Divergent Trilogy Movie. 2014. Summit Entertainment. A Lionsgate Company. USA. 
Humanika, Vol. 16, Nomor 1, September 2016 